\title{
THE ENVIRONMENTAL IMPACTS OF LAND TRANSFORMATION IN THE COASTAL PERIMETER OF THE MAR MENOR LAGOON (SPAIN)
}

\author{
S. GARCÍA-AYLLÓN ${ }^{1} \&$ J. L. MIRALLES ${ }^{2}$ \\ ${ }^{1}$ Department of Civil Engineering, Technical University of Cartagena, Spain. \\ ${ }^{2}$ Department of Urban Planning, Polytechnic University of Valencia, Spain.
}

\begin{abstract}
The Mar Menor, a coastal lagoon located in the southeast of Spain, is one of the largest lagoons on the Mediterranean coastline. This singular area is subject to a wide range of uses, including large tourist resorts and intensive agriculture. The importance of the lagoon and its salt marshes in terms of biodiversity has been recognised in numerous international protection programmes.

The distinctive environment of the lagoon has long been attractive for visitors. A surge in tourist activities has taken place in the area since the early 1960s, characterised by intense urban development along the lagoon's perimeter to accommodate the growing seasonal population. This phenomenon has particularly affected La Manga, a sandy bar that is $20 \mathrm{~km}$ in length. La Manga acts as a barrier between the lagoon and the Mediterranean Sea, crossed by five more or less functional channels called 'golas'. The urbanization process has changed the water flow system between the inside and seawater through the channels. The changes have affected coastal dynamics, the longitudinal profile of the coast and the lagoon's ecosystem. The coastal lagoon is also highly threatened by other pollution variables derived from agricultural lands. The water derived from the Tajo-Segura transfer generated a profound land transformation of the adjacent agricultural areas, which changed from extensive dry crop farming to intensively irrigated crops, disturbing the lagoon dramatically.

This paper analyses both land transformations around the coastal perimeter of the Mar Menor during the last 50 years and shows the environmental impact with its consequences on the ecosystem. Although numerous biological studies have been carried out in the Mar Menor, a better understanding of the consequences of land transformation in the perimeter of the lagoon is still necessary to understand the lagoon's situation. The results of territorial management in the Mar Menor lagoon need to be addressed in order to develop successful strategies in the area to protect this valuable ecosystem and its services.

Keywords: Land transformation, coastal developmentalism, Mar Menor lagoon, La Manga, environmental impact, agriculture pollution.
\end{abstract}

\section{INTRODUCTION}

The Mar Menor is a salt water lagoon (between 135 and $170 \mathrm{~km}^{2}$, mean depth $3.6 \mathrm{~m}$, maximum $6 \mathrm{~m}$ ) located in the Region of Murcia, a semi-arid region of southeast Spain. This area is characterised by scarce precipitation ( $<300 \mathrm{~mm}$ per year) that mainly occurs during storm events in autumn and winter. The lagoon is isolated from the Mediterranean Sea by a 20-km-long and 100- to 900-m-wide ancient sandy bar, now highly urbanised (called La Manga) and crossed by five very shallow channels (Fig. 1).

The balance between the internal waters of the Mar Menor and the waters of the Mediterranean Sea is maintained by regulation actions of three of these communication channels that allow the water flow between them. These three channels are the 'gola of Marchamalo', the channel of 'Estacio' and the 'encañizada del Charco'. They are navigable and, historically, have been used for fishing. The average water residence time inside the lagoon is 0.79 years [1]. Due to its location between land and sea, the Mar Menor lagoon is subject to an elevated rate of dynamic changes in the natural environment that result in high biological productivity and diversity. 


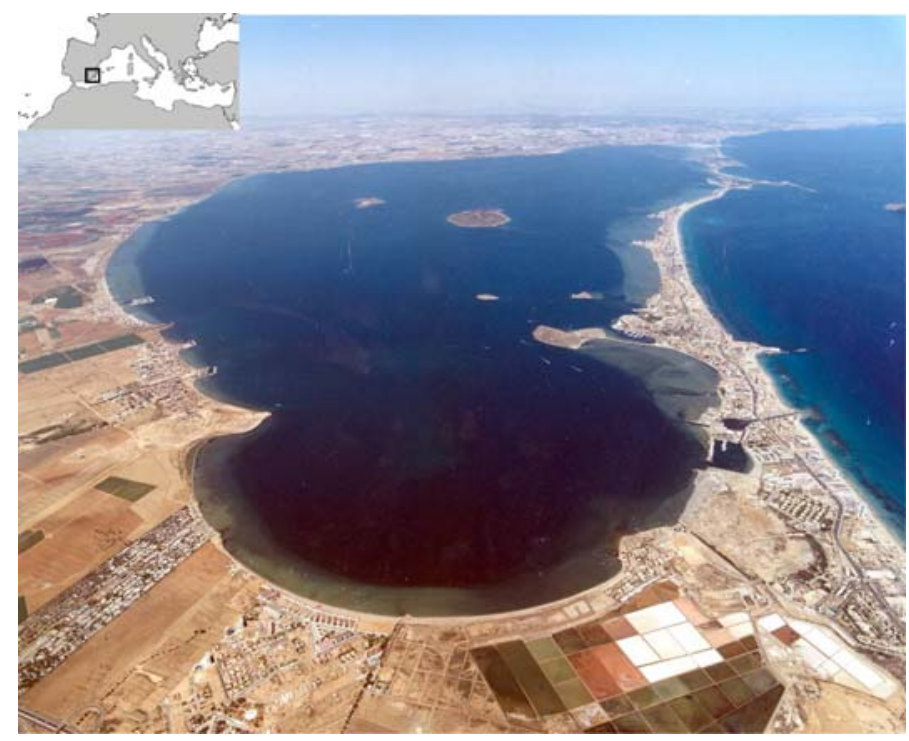

Figure 1: Mar Menor: view from south. Source: Atlas de la Región de Murcia.

In 1994, the Mar Menor was considered part of the important RAMSAR list (Convention on Wetlands, with 15,000 ha designated as wetlands of international interest all over the world). This is due to the high natural value of the area and its many species of birds. It was recently proposed that it should be a Specially Protected Area of Mediterranean Importance (SPAMI) under the Convention for the Protection of the Marine Environment in the Coastal Region of the Mediterranean.

The lagoon and the associated watershed areas support a whole variety of human uses including large tourist resorts and intensively irrigated agriculture. In the field of tourism, the problem of seasonality concentrating uses and urbanization in the area (July to September) is evident when the number of the permanent local population (of about 45,000 inhabitants) is compared to the tourist population reached (about 450,000 during summer months) [2].

As noted, the Mar Menor environment is fundamentally conditioned by the joint action of two activities: tourism and agriculture. Both have produced a deep and extensive transformation of the territory surrounding the Mar Menor in recent decades, altering some of its most important natural elements.

The situation of both differs geographically, while at the same time their impacts on the salt lagoon are very different. On the one hand, the east facade adjacent to the Mediterranean Sea has several impacts of hypertrophied urbanization generated by mass tourism. The indicated seasonal tourism, in addition to sewage generated on the salt lagoon, has an important effect on coastal dynamics. This impact is further accentuated by the so-called 'Mediterranisation process' that is occurring in one of its five ruffs, the Estacio, which will be discussed later.

On the other hand, several watercourses discharge runoffs from different basins on the west side of the lagoon. This territory contains the agricultural area known as the Campo de Cartagena. The joint action of both phenomena is summarised in the following map (Fig. 2).

This paper is a summary of the environmental impacts that have occurred in the geographical area of La Manga as a result of the urban development occurred after 1960 and that have been discussed primarily in a $\mathrm{PhD}$ research [4]. 


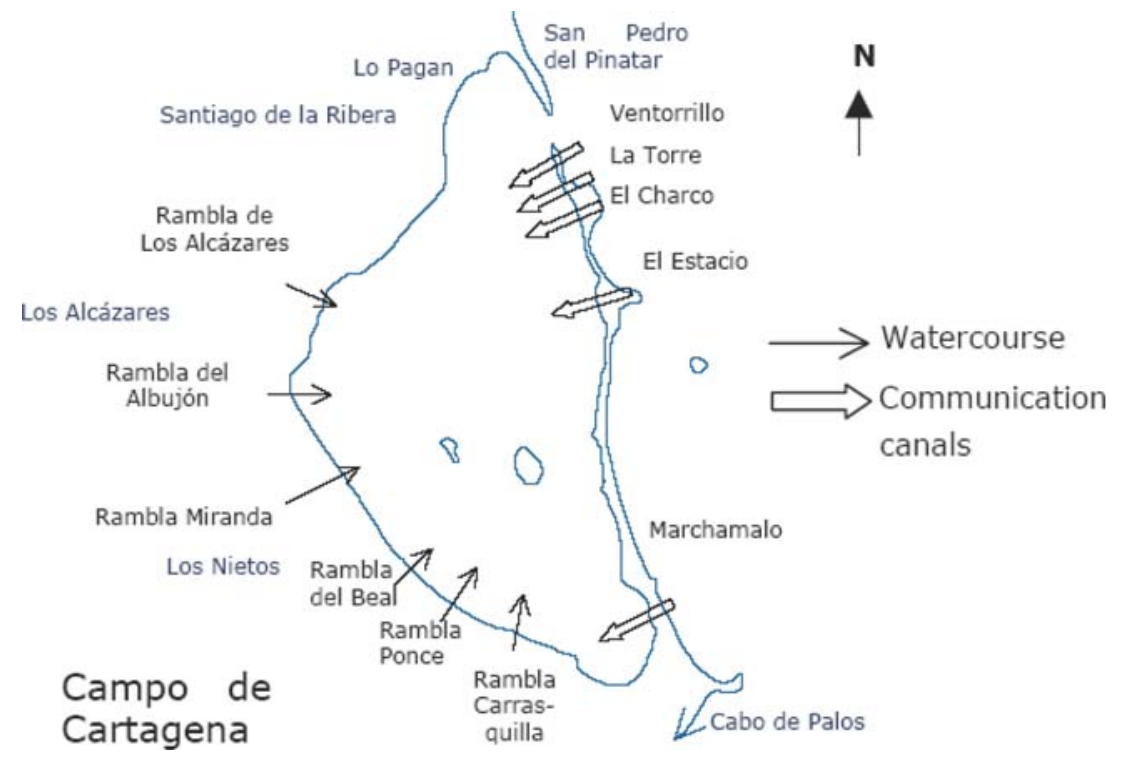

Figure 2: Diagram of watercourses flowing into the Mar Menor and communication canals between the lagoon and Mediterranean Sea. Source: [3].

\section{GIS ANALYSIS OF LAND TRANSFORMATION: COASTAL URBAN DEVELOPMENTALISM AND AGRICULTURAL ACTIVITIES}

The transformation of soil that has occurred in the surroundings of Mar Menor in the last 50 years, as a result of tourism and agriculture will be analysed. This will be carried out using the GIS programs IDERM and Cartomur, created in the Region of Murcia for geospatial analysis and evaluation [5].

In the case of tourism, the urbanization of the coastline in the Mar Menor began mostly in the 1960s with the Law of Centres and National Tourist Interest Areas of 1963, which allowed the accelerated construction of the $20 \mathrm{~km}$ of La Manga (Fig. 3). In addition to this situation, one must add the expansion on the continental front of the Mar Menor from some coastal towns such as San Javier, Los Alcazares and San Pedro del Pinatar through tourism (Table 1).

The construction of marinas, the widening of the natural ruffs to allow the passage of pleasure crafts, and the construction of landfills for land reclamation and other projects (such as roads to communicate the ancient dunes with the outlying islands) have altered the coastal dynamics and La Manga sedimentary flow. The changes in the ecosystem during years have generated visible results with consequences that are appreciable nowadays.

Looking at the coastal topography of the Region of Murcia at a certain scale, a clear contrast in the degree of urbanization of the northeastern coastline bordering the province of Alicante (where the Mar Menor is) and the coast reaching the south to Andalusia can be seen.

This distribution generates a strong territorial asymmetry that has concentrated its urban impact on the northeastern coast around the Mar Menor. This makes the Region of Murcia paradoxically one of the globally less anthropised regions of the Mediterranean coast in Spain (Table 2).

This configuration is not due to a special protection degree on coastal environmental protection or a particular spatial policy, but it is the result of the so-called 'urban sink effect' of La Manga. This phenomenon concentrated the whole development activity around La Manga and the Mar Menor causing high inertial anthropisation on its coast and ecosystems [6]. 

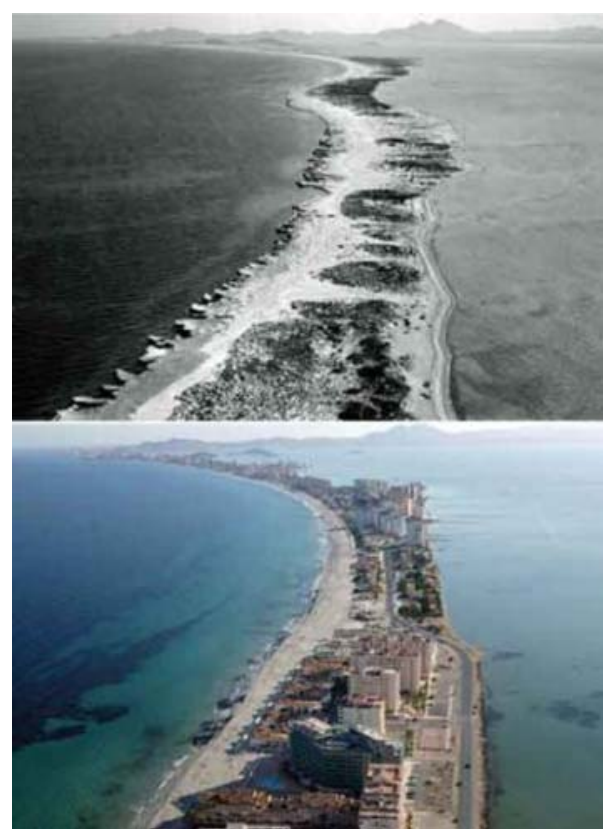

Figure 3: Images of La Manga in the 1950s and now. Source: Paisajes Españoles Inc.

Table 1: Population growth since 1991 in the area of the Campo de Cartagena.

\begin{tabular}{lccccc}
\hline & 1991 & 1995 & 2000 & 2005 & $\%$ \\
\hline Alcázares (Los) & 3,683 & 4,779 & 7,513 & 12,264 & 192 \\
San Javier & 14,696 & 17,282 & 18,925 & 26,337 & 89 \\
San Pedro del Pinatar & 12,057 & 13,916 & 15,583 & 19,666 & 61 \\
Campo de Cartagena area & 226,532 & 241,876 & 269,425 & 319,153 & 33 \\
Region of Murcia & $1,009,743$ & $1,086,464$ & $1,149,328$ & $1,335,792$ & 26 \\
\hline
\end{tabular}

Source: IDERM and authors.

The aforementioned inertia materialises especially in very specific actions. The effects and results can be assessed by establishing different hypotheses about the boundary conditions of coastal dynamics. The alteration of the natural shoreline defined by the initial dunes started in the 1960s with the construction works in La Manga. The road that crosses longitudinally along the ancient sandy bar gains land in different parts of the sea, changing the sediment dynamics of the beach.

The impact of tourism development on coastal dynamics is mainly concentrated in La Manga, in an erosion-accumulation process. On the external part, an overall regression of the beach has been observed on the shore of the Mediterranean Sea. A volcanic crest extends in parallel along the coast, $200 \mathrm{~m}$ from the Mediterranean and $2 \mathrm{~m}$ deep, which protects La Manga from the erosive effect of the most powerful waves. It has been observed that where this outcrop is interrupted, greater erosion is produced on the beaches in front of it. 
Table 2: Percentage of urban land in the Spanish Mediterranean coast.

\begin{tabular}{lcc}
\hline Area & Coast $(\mathrm{km})$ & $\begin{array}{c}\text { Artificial uses in coastal } \\
\text { fringe } 2 \mathrm{~km}(\%)\end{array}$ \\
\hline Girona & 260 & 25.0 \\
Barcelona & 161 & 54.0 \\
Tarragona & 278 & 28.2 \\
Castelló & 139 & 23.5 \\
Valencia & 126 & 28.7 \\
Alacant & 244 & 49.4 \\
Murcia & 274 & 13.6 \\
Almeria & 249 & 13.1 \\
Granada & 81 & 10.6 \\
Málaga & 308 & 49.3 \\
Spanish Mediterranean & 2.029 & 28.8 \\
coast & & \\
\hline
\end{tabular}

Source: Ministerio de Agricultura, Alimentación y Medio Ambiente [6, 7].

On the shore of the Mar Menor, the internal part of La Manga, a regression has been observed because wind transportation that feeds the zone has been broken by the urbanization and the process of making the dune system more rigid.

On the other hand, the northern part of the Mar Menor is characterised by its accumulation processes. The mud filling process is starting to be a problem for tourist activity. An appropriate estimation of sedimentary velocity may be $1.2 \mathrm{~mm}$ per year and $2.0 \mathrm{~mm}$ per year for the last 80,000 years [8]. Only by natural mechanisms, without human intervention, the system can fill itself for the next 6,000 to 8,000 years.

However, other uses and parameters also affect the Mar Menor. Figure 4 is a representative diagram of the mainland uses across the area of the pilot site.

A wide variety of uses can be observed, which implies a great deal of pressures on the environment and constant conflicts between the different uses. Traditional uses such as salt, mining and fishing are losing ground now that they are confronted by the constant growth of tourism and urbanization, especially in La Manga area.

Among these impacts, the most important is that produced by the transformation of land for agriculture. In the mid-1980s, water derived from the Tajo-Segura river transfer generated a profound transformation of the agricultural practices and activities in the adjacent agricultural area, the Campo de Cartagena, which changed from extensive dry crop farming of cereals, olives, almonds and carob beans to intensively irrigated crops. Today, the Campo de Cartagena is one of the most productive and profitable agricultural areas in Europe, but the use of water, fertilisers and pesticides has increased dramatically.

At present, in the Campo de Cartagena plain, there is a cultivated area of 144,000 ha (Fig. 5). By carrying out a GIS evaluation (Fig. 6) of the territory affecting the Mar Menor, it can be seen that most of the land transformation was performed during the periods of 1976-1988 and 1999-2007.

In the case of tourism, the land transformation was concentrated in the south of La Manga in the 1970s and 1980s and from 1990 until 2007 on the coastal front of the mainland. Agriculture has had 


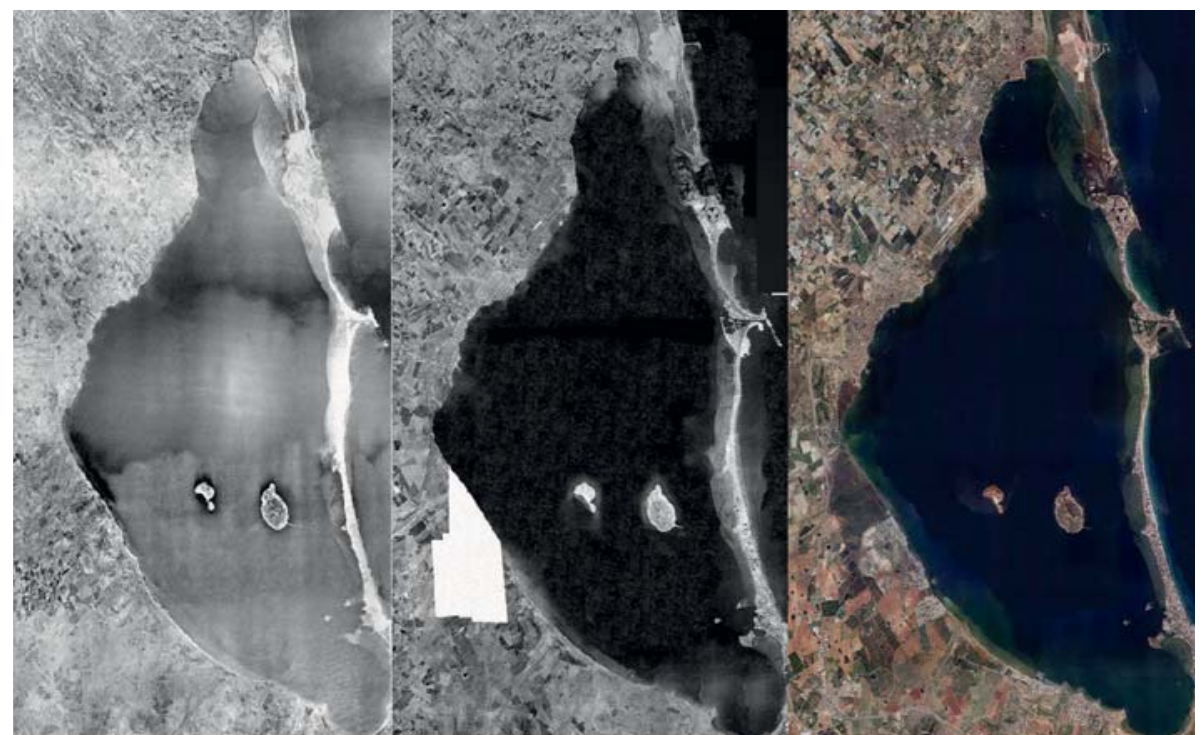

(a)

(b)

(c)

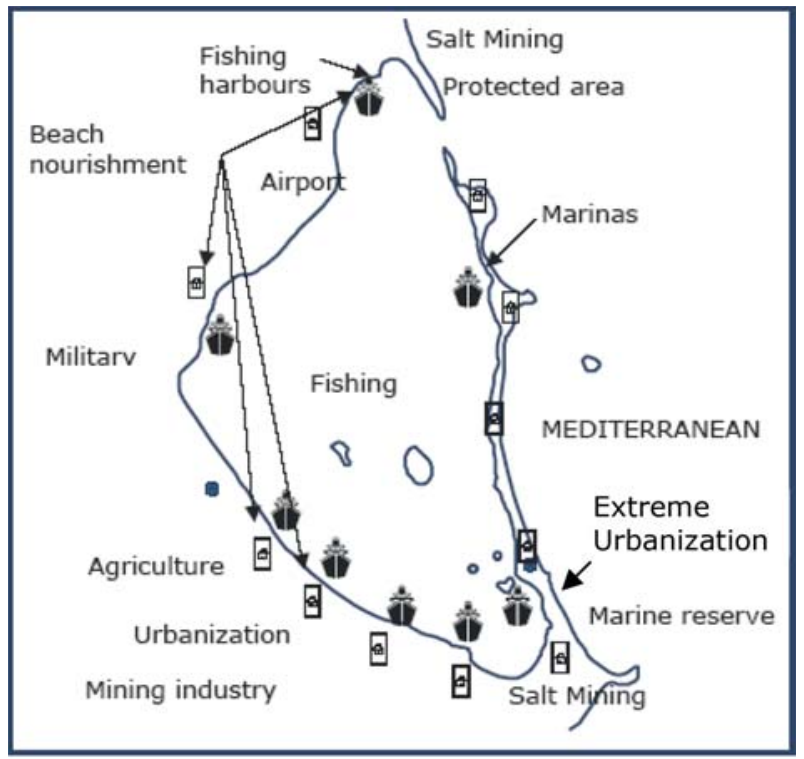

(d)

Figure 4: GIS analysis of the Mar Menor main uses and activities: (a) 1956, (b) 1981, (c) 2007 and (d) schematic uses. Source: IDERM [3].

exponential growth but only in the municipalities of the continental territory, due to the water provided by the Tajo-Segura transfer.

A larger plot development and the agricultural transformation were observed in the vicinity of the wadis that flow into the Mar Menor. These are located mainly in the municipalities of Cartagena and 


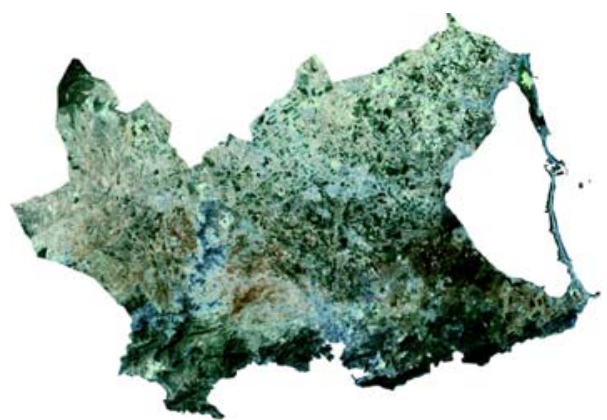

Figure 5: Campo de Cartagena cultivated area. Source: IDERM.

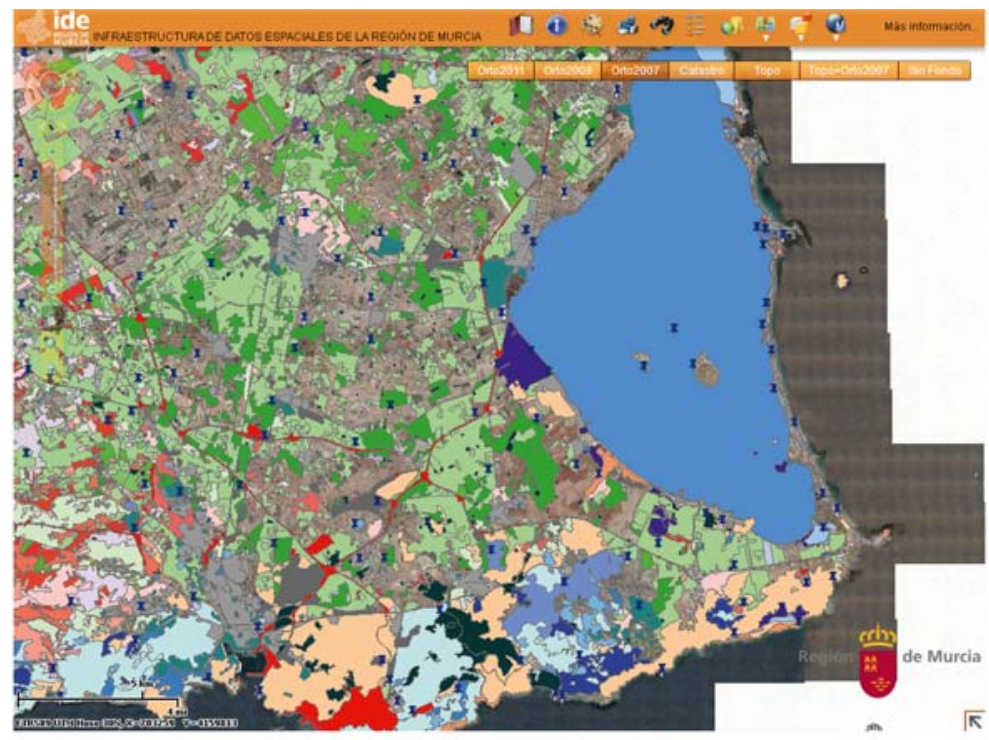

\begin{tabular}{|l|c|c|c|c|c||c|}
\hline Municipalities & 1961 & 1979 & 1999 & 2003 & $\begin{array}{c}\text { Difference } \\
1961-2003 \\
\text { (Ha) }\end{array}$ & $\%$ \\
\hline Cartagena & 2.226 & 5.642 & 13.658 & 13.658 & 11.432 & 513 \\
\hline Fuente Álamo & 760 & 1.281 & 1.767 & 2.649 & 1.889 & 248 \\
\hline San Javier & 1.342 & 1.248 & 3.826 & 3.826 & 2.484 & 185 \\
\hline San Pedro de Pinatar & 163 & 1.659 & 1.411 & 1.411 & 1.248 & 765 \\
\hline Torre Pacheco & 559 & 4.565 & 14.623 & 15.353 & 14.794 & 2.646 \\
\hline $\begin{array}{l}\text { La Unión } \\
\text { Campo de Cartagena } \\
\text { area }\end{array}$ & 5.087 & 176 & 399 & 399 & 362 & 978 \\
\hline $\begin{array}{l}\text { Whole Region of } \\
\text { Murcia }\end{array}$ & 70.702 & 123.137 & 35.684 & 37.296 & 32.209 & 633 \\
\hline
\end{tabular}

Figure 6: GIS evolution of irrigation development in the area of the Campo de Cartagena 1961-2003. Source: IDERM and authors. 
Torre Pacheco. In the latter, the growth of the agricultural land has led to ground transformation, creating an increment of agricultural soil of $2700 \%$ in the last 40 years.

\section{ASSUMPTIONS AND CONSIDERATIONS OF ENVIRONMENTAL IMPACTS ON COASTAL DYNAMICS OF THE MAR MENOR AND LA MANGA}

Among the large list of environmental impacts of the Mar Menor, those related to the modification of coastal dynamics of the coast are among the most important. In this field, interesting results in the alteration of both sedimentary sand flows (longitudinal and cross sectional) are found. This phenomenon is particularly intensely concentrated within the $20 \mathrm{~km}$ of La Manga.

In the longitudinal case, the gullets alteration, the modification of the coastline due to landfills and the construction of marinas or any other element causing obstruction to the traditional Mediterranean north-south sedimentary flow are especially critical. A brief review of them should be done before to analyse the degree of impact.

First, there are several performances such as the landfill of the Viveros area (Fig. 7) and the construction of roads to connect the satellite islands of the Mar Menor with La Manga (Fig. 8). These buildings significantly disrupt longitudinal sediment flow of the urbanization area, thus creating a breeding ground whose results will surface years later and are difficult to quantify a priori [6].

Some of these actions such as the road connecting from the Ciervo island to La Manga were dismantled by a court judgement after long, drawn-out legal proceedings that demonstrated its negative

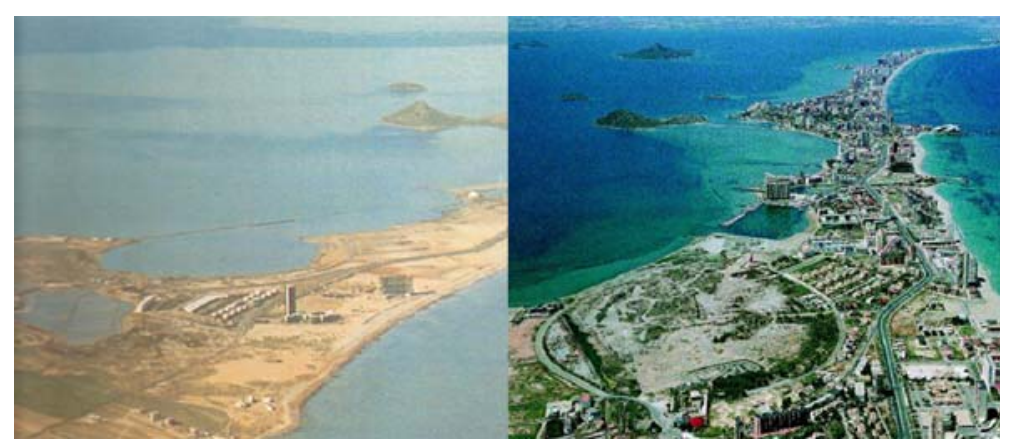

Figure 7: The Viveros lagoon before and after fill in 1963 and 2007 (images archive VECOS Company).

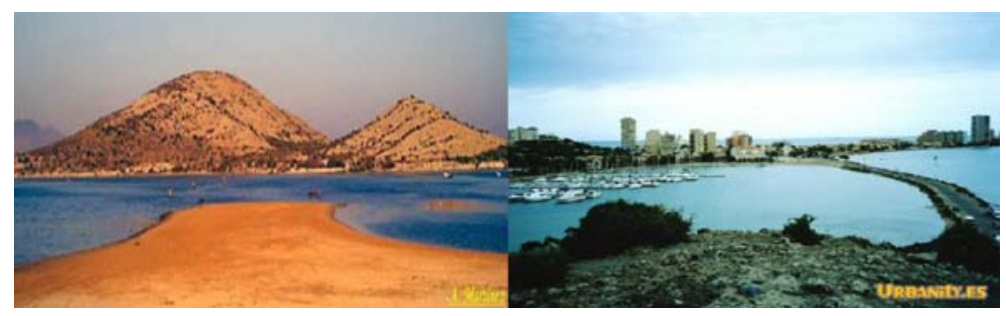

Figure 8: The Ciervo island without (1963) and with road connection (1989) (images archive URBANITY Company and personal archive of A. Martínez). 
impact on the ecosystem (by waterlogging and on the balance of the sandbar dune by longitudinal sediment flow interruption). However, other controversial actions such as landfills were consolidated or remain awaiting a court judgment like Puerto Mayor marina, given the difficulty of establishing an undeniable technical assessment of its environmental impact.

In the case of the direct impact on the longitudinal flow, the estimations shown in some studies using the empirical model of the Coastal Engineering Research Center (CERC) [9] initially targeted a net transport of sediment from north to south evaluated in $247,000 \mathrm{~m}^{3} /$ year. The CERC model applied in this study [10] for La Manga relates the volume of carriage with a dimensionless empirical coefficient $\left(0.014 \cdot \mathrm{H}_{\text {sig }}\right)$ and the component of the wave energy flow, giving good practical results in American coastal environments. Nevertheless, it had various limitations such as its inability to consider textural variations of the background material (CERC is only valid for $0.2-0.5 \mathrm{~mm}$ diameter sands, not exactly those of La Manga), its failure to consider the slope of the beach, the diffraction effect of rock ledges, islands and levees, and events such as the distribution of transport in the surf zone. Hypothesis such as limiting the wave height to a range of $1.5 \mathrm{~m}$ due to energy dissipation taking into account the presence of a cemented sand bar near the coast in many sectors would give transport volumes well below $100,000 \mathrm{~m}^{3} /$ year.

Considerations like these have also led to a question the assumption that the main component of drift in La Manga is from north to south, against the evidence of the continued erosion in southern beaches near Cape of Palos. This hypothesis has traditionally been supported by the fact that sand dune fields of La Manga are concordant in their mineralogical composition with the contributions of the Segura River at its estuary (in Guardamar, north of La Manga).

This flow would theoretically create, for example, in Cape of Palos, wide beaches in the north because of the barrier effect generated by the significant sediment volume derived. The absence of these wide beaches is probably exaggerated in the studies; according to this disagreement with the actual behaviour of the beach, it is possible that the real flow may not exceed $60,000 \mathrm{~m}^{3} /$ year [6].

Even so, it is very clear that the human effect has generated various acceleration processes. In Spain, the construction of over 700 dams as a flow switch of fluvial sediments in the past 50 years was in the last decades on the basis of the accumulated deficit of the coastal sediment budget. Nevertheless, in La Manga, the contribution of rivers is not the distorting variable of the sedimentary dynamics that have modified the coastline in recent decades. It is the artificial partitioning of the coast in sedimentary cells with dikes and breakwaters (bathymetry support below the storm wave action) and the occupation of the dunes that have had dramatic synergistic effects causing extensive coastal erosion, and forcing administrations to refill beaches artificially to maintain their width.

In this field, the three most influential performances in La Manga sedimentary imbalance are:

1. The port of San Pedro del Pinatar acts as a total barrier to longshore sediment transport in a southerly direction. The effect of entrapment inside the port has led to a reduction of drafts and the continued development of a beach up to the counterdike. In historical cartography, the widespread heavy erosion in the south of the port can be seen, following the extension of their dikes during the years 1947-1957, reaching retractions of up to $5 \mathrm{~m} / \mathrm{y}$ ear in the Mediterranean edge, which subsequently were compensated during the following decades.

2. The communication areas of weirs in the north of the Mar Menor, which act as sediment trapping areas, facilitate their entrance to the lagoon. They are defended from storms by small rocks, remains of a cemented sand bar near the coast, whose degradation could lead to a substantial increase in the wave energy that came to the northern beaches of La Manga. This line of rocks creates a corridor for the transport of sediments. This has led to the appearance of a concave beach between Punta Pudrider and Punta del Cocedor as a result of a huge imbalance of sediment, which 


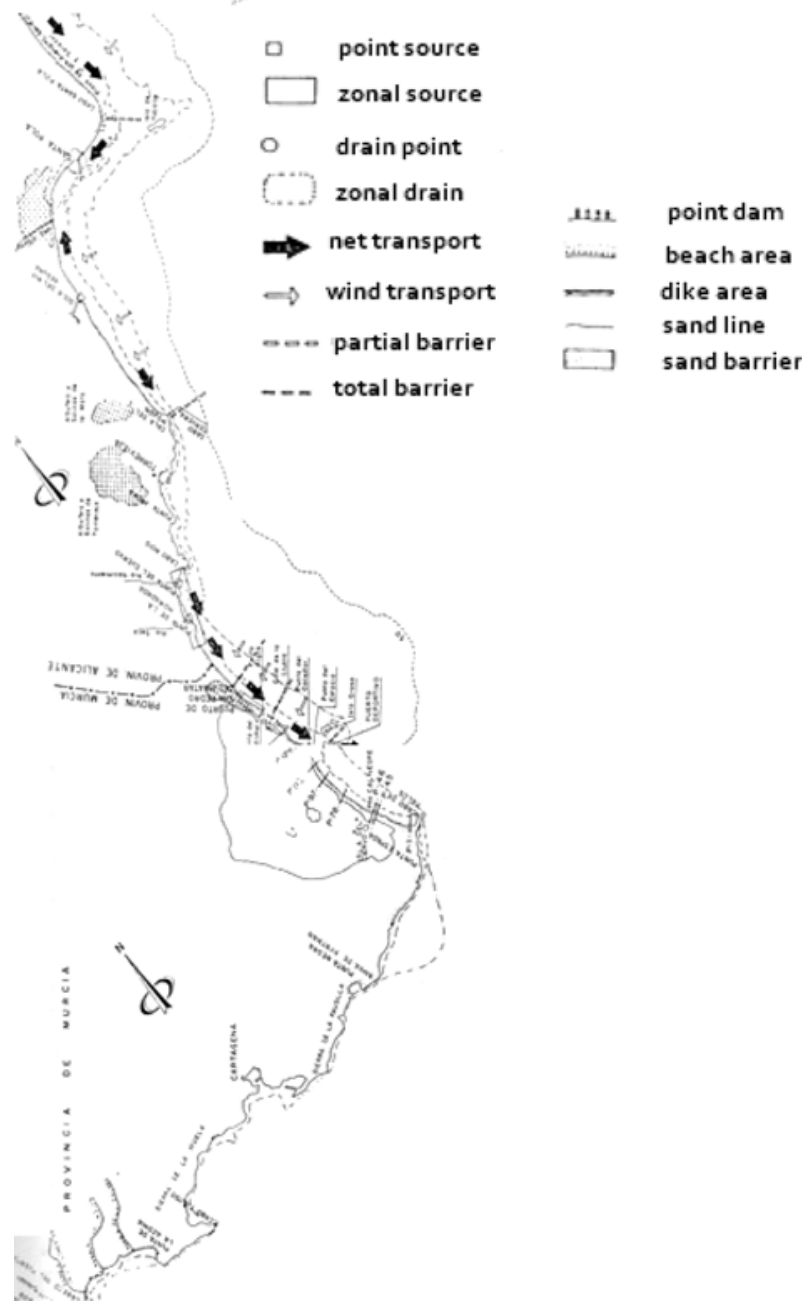

Figure 9: Historical study about coastal dynamic. Source: Ministry of Public Works of Spain [11].

rolls back the waterfront to achieve stability. This is the most vulnerable sector of La Manga with regard to its geomorphology. A high variability in forward or reverse coastal movements has been appreciated [10], with ranges from 32-48 m of erosion between the period 1947 and 1957 to 15 $m$ of coast degradation during the period 1957-1972 (Fig. 9).

3. The third and most important factor in the above list would be the Tomás Maestre port, whose expansion called Puerto Mayor (halted by court order) would turn it into the largest marina in Spain. This sediment transport barrier also blocks longitudinal sediment arrival, stripping the sand from theoretically southern beaches of La Manga. Although there is no guarantee that it is not responsible for the major coastal recession experienced by the beaches during the last decades, this infrastructure is behind a phenomenon called the 'Mediterranisation' process of the Mar Menor. 
By occupying the old ruff of the Estacio, the construction and dredging of the channel in 1973 for the passage of vessels has been a sink element for the sediment transport flow. Upon entering the Mar Menor, this creates an imbalance in the beaches that causes erosion rates of approximate $1.5-2 \mathrm{~m}$ per year. However, blaming the port in this matter is not entirely justifiable, because it must be remembered that it chronologically overlaps its construction with the urbanization process of La Manga. This process, with its construction at the expense of destroying the dune fields that played a decisive role in sediment supply to beaches (acting as insurance for the stability of the string with its role as sand reservoir), is possibly linked to the progressive erosion process of some beaches on the inner side of La Manga.

Apart from the problem of coastal dynamics, there is the impact on the existing ecosystem in the Mar Menor itself. The Mar Menor is an unusual lagoon with little depth (Fig. 10) and fragile flora and fauna of a great value.

A conclusive effect of the environmental impact of the so-called phenomenon of 'Mediterranisation' is the mutation process inside the ecosystem of the largest lagoon in Spain. In this sense, the data on results are unquestionable (Table 3):

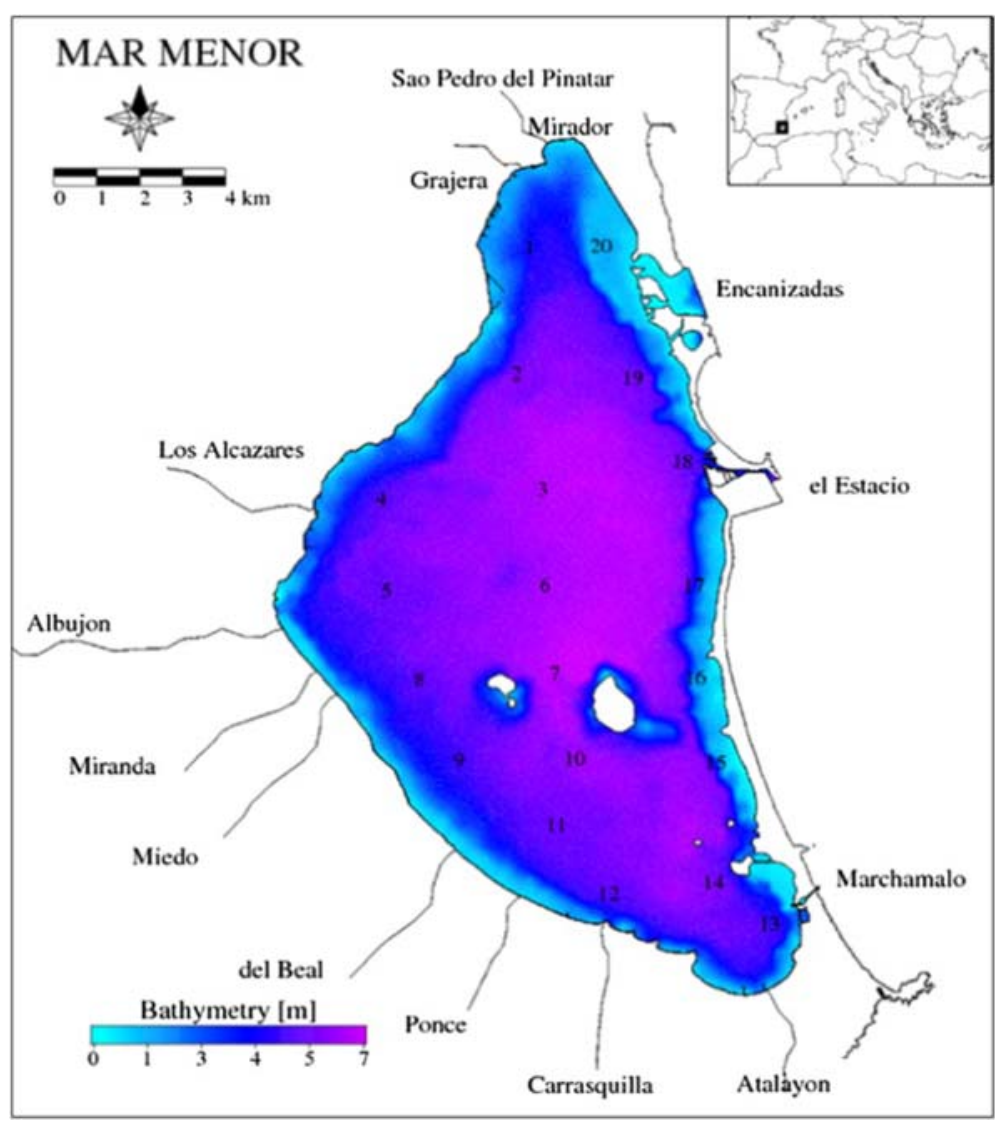

Figure 10: Bathymetry in the Mar Menor. Source: [9, 12]. 
Table 3. Changes in Mar Menor ecosystem in the past 20 years.

Water salinity

Water temperature

Alteration of biota

Disappearance and introduction of new species
Salinities were lowered from $53 \mathrm{~g} / \mathrm{l}$ to the maximum current values of $47 \mathrm{~g} / \mathrm{l}$

Have softened in $2{ }^{\circ} \mathrm{C}$ annual temperature extremes

In phytoplankton, species number multiplied by 10 and the fish and shellfish by 2 , with the appearance of new taxonomic groups, such as echinoderms.

Common species have disappeared, such as shrimp and eel, others such as the seahorse have spread. Other species have become invasive in space, such as Caulerpa prolifera (occupation up to $95 \%$ of the sandy bottom) and jellyfish Pelagia noctiluca, Rhizostoma pulmo and Cotylorhiza tuberculata. Jellyfish have become, in some years, a real plague reaching 60 million individuals that have saturated the salty waters of the lagoon.

Source: [6].

To really know the consequences of the construction and dredging of the Tomas Maestre port and what would be the impact of Puerto Mayor, it is necessary to know accurately the real exchange of volumes produced in the Estacio channel between the Mar Menor and the Mediterranean Sea. According to Arévalo Díaz del Río [9], the main exchange between the two seas occurs in this channel. Therefore, these exchanges are not significant in the Marchamalo ruffle in the south (due its problems of blinding in the estuary) and in the weirs of the north (due to the low flow movement by their limited depth). In simple terms, it can be summarised that the exchange of water between the two seas is due to the forces caused by tides and atmospheric agents, mainly by the atmospheric pressure in the Estacio.

Modelling the resultant force as the difference between the levels of both seas $\Delta \mathrm{h}$, the rate of movement can be assimilated to the principle of 'communicating vessels'. According to simple equations of hydraulics, this height difference would be given in the absence of other constraints on longitudinal and cross-sectional velocities $\mathrm{u}$ and $\mathrm{v}$ of the stream: $\mathrm{u}=\Delta \mathrm{h} \cdot \mathrm{g} \cdot \mathrm{W} /(v \cdot \mathrm{L})$, where $\mathrm{g}$ is gravity and $\mathrm{L}$ and $\mathrm{W}$ are the length and width of the channel [10].

The studies presented as justification for the environmental impact project of Puerto Mayor showed by implementing stream meters that, usually the cross-sectional velocity in this area is from the south and remains stable to environment values of $0.1 \mathrm{~m}$ per sec. Assuming gravity as a constant and keeping the width $\mathrm{W}$, it may be concluded that although the works in the past have emphasised the sink effect of the Estacio channel toward the Mar Menor (causing the 'Mediterranisation' phenomenon in its waters), it is also true that the safe completion of the work approved by the High Court of the Region of Murcia would not pose a significant impact on the environmental balance (Fig. 11).

This result is due to the conditions of entry of the channel (in the direction of movement from the Mediterranean to the Mar Menor). They have not changed substantially because the current is already forced by the Levante dock built in the 1970s, entering SE-NW (considering a static regime in the channel where currents exist). In this case, the completion of the dike before the channel increasing the length (L) of $1500 \mathrm{~m}$ to $2150 \mathrm{~m}$ would represent a more positive impact, making it necessary to establish a final balance in the coastal dynamics. 


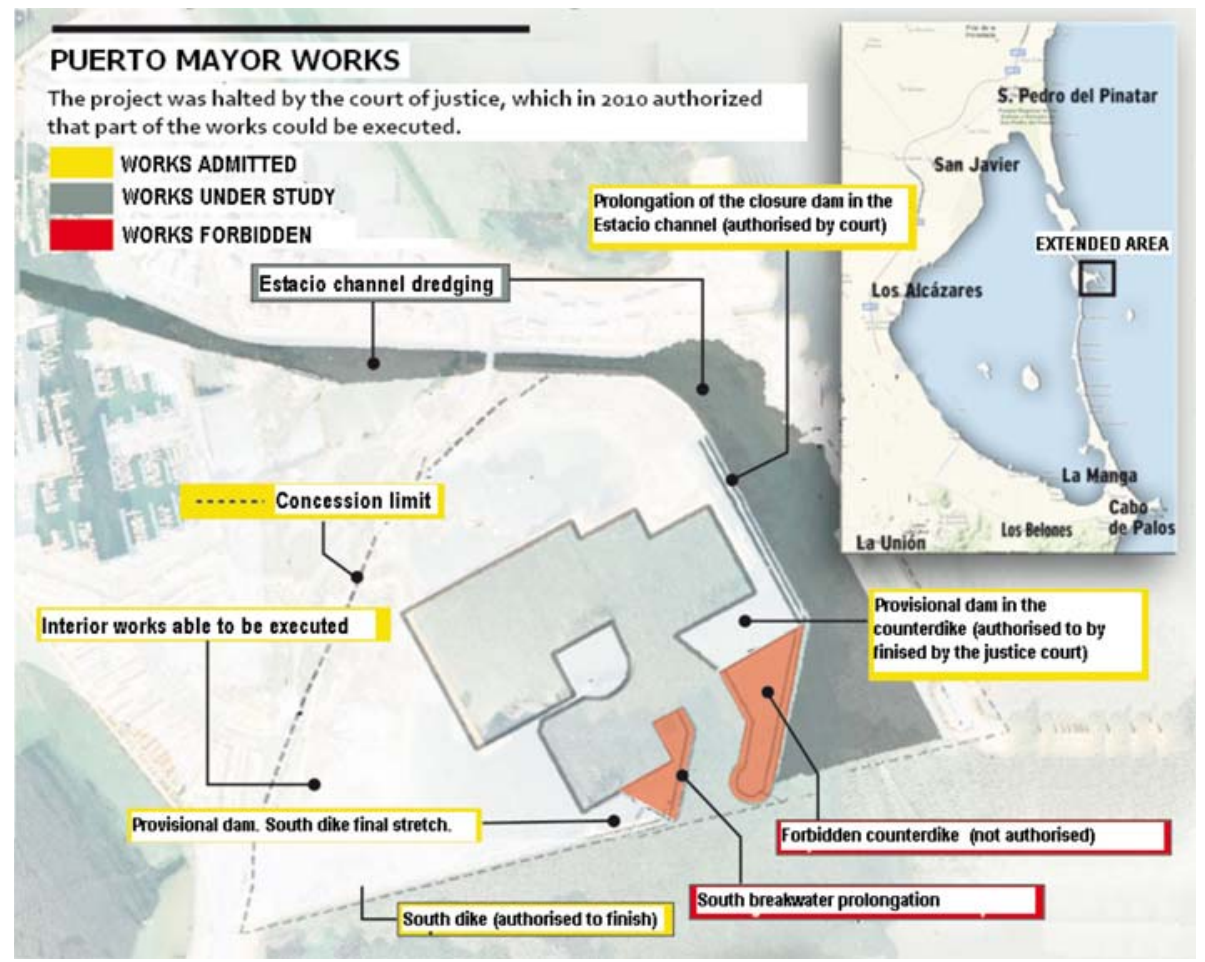

Figure 11: Works admitted and forbidden in Puerto Mayor by the High Court of the Region of Murcia in 2010. Source: La Verdad Newspaper 19/07/2010, based on [13].

But these findings are not conclusive and often do not match the movements of the coastline, which has required sand fill in the last decades (Fig. 12). Many of the hypotheses used are based on the work done by the Ministry of Public Works in 1979 [14], which envisaged the Mar Menor as a sink for materials on the stretch of Cape Roig to Cape of Palos, producing the dragging of materials towards the south. The source material was consistent with the contributions of the watercourses of the rivers Seco and Nacimiento in Alicante, as well as orthogonal dragging from the coast. The ruff of Estacio supposed as it was indicated a partial barrier, as it is suggested by the place names sited on the north: the 'Punta Algas' and 'El Pudrimel' (meaning in Spanish, areas of waterlogging). The dredging of the channel and construction of the dike of Levante in theory multiplied the effect creating a total barrier, with the combined action of point and ruff. However, there is also the possibility, not addressed by the comparative studies of the Ministry (rigorous in historical perspective, but not so in the presentation of hypotheses) that the channel could constitute a source of supply of materials instead of being a sump.

This new hypothesis would be based on different facts, such as the character prior to the construction of the levees on the Mediterranean coast; there was a natural line from Punta El Estacio to Isla Grossa. This was constituted by a succession of reefs and rocky low spots that only by its normal direction to the dominant wind EN did not seem to have become a sandy isthmus. In addition, it seems in the calculation itself of the Levante levee, which was built on rock to protect it from storms, this construction only demanded (despite its orientation) lifting a height above sea level of between 3 and $5 \mathrm{~m}$. This may be due to the poor depths that included the wave design (under the Levante dock 


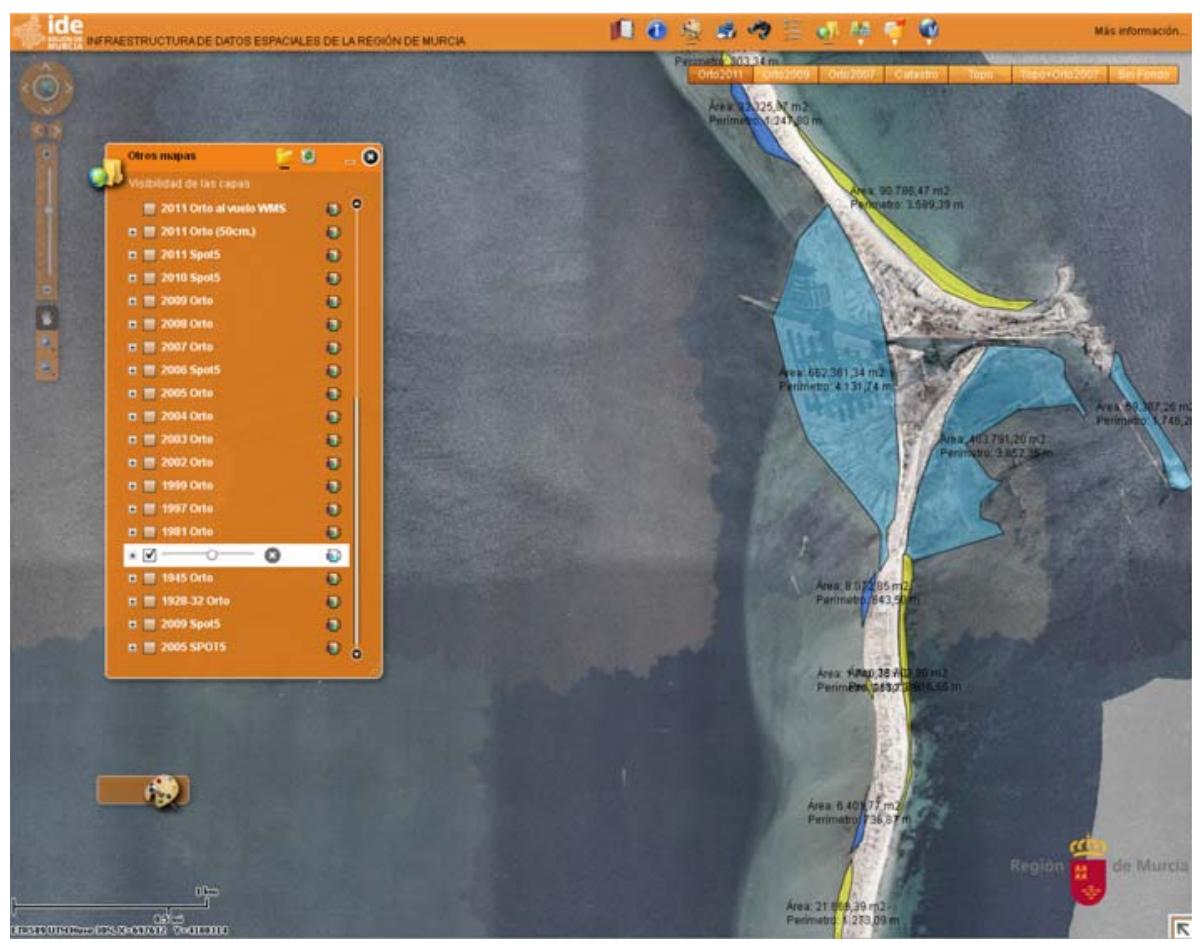

Figure 12: Environmental impact of Puerto Mayor and Puerto Menor in the La Manga coastline: beach nourishments and artificial reclaimed land between 1956 and 2011. Source: IDERM and authors.

the depth ranged only about $2 \mathrm{~m}$ and between Isla Grossa and the levee the maximum depth is not more than $5 \mathrm{~m}$ ). Thus, it is conceivable that in the vicinity of the tip of the Estacio the north-south current generated seaweed and sand deposits on the north side and was diverted westward moving in reality away from the edge of the coast.

Similarly, the different impact produced by the different elements built must be pointed out; arguably, the most environmentally damaging were those executed in the 1960s and 1970s. In other cases, however, like the south dock (parallel and very close to the natural one of Punta El Estacio), its influence is negligible, instead of the theoretical beneficial effects expected against waves. These effects, due to regression in that area, are well known in the Mediterranean beaches further south. The proof is, for example, the location of the outfall south of El Estacio (in 1979, a wastewater treatment plant was projected, which five years later was approved and proceeded to stake out, and in 1984, it had to be stopped on account of the fact that those beaches had a regression of $20 \mathrm{~m}$ ). On the other hand, for example, the bass line linking Punta del Estacio with Grossa Island is a wholly unpredictable element whose role in this phenomenon is virtually unknown and more worthy of serious study.

It must be said that the attention to environmental issues in the Mar Menor is often fixed in the Mediterranean seafront of La Manga, forgetting the other front of the ancient dune. This has happened because of tourist interests. Specifically, the beaches of the Mediterranean coast of La Manga lose sand continuously and there are periodical artificial contributions of sand. But despite common belief, the most damaged area by the absence of sediment input is the facade of La Manga to the Mar Menor 


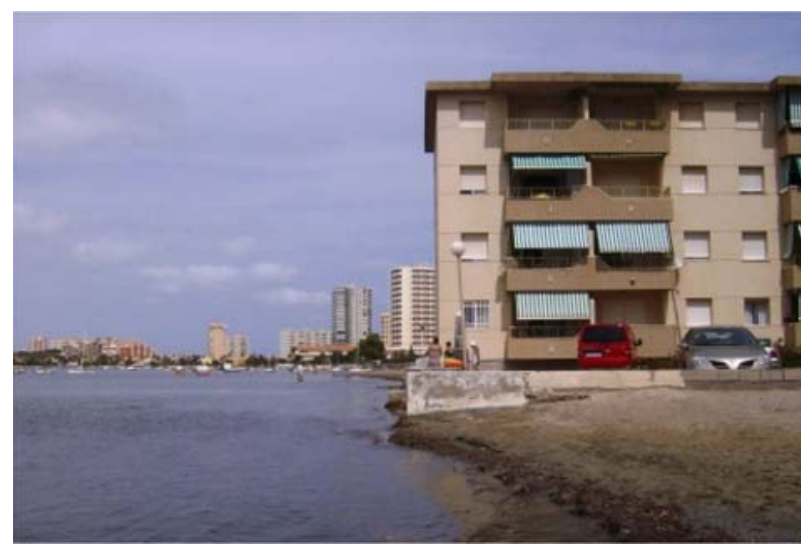

Figure 13: Retreat beaches in facade of La Manga to Mar Menor lagoon. Source: authors.

lagoon. This is due to the lack of contribution from the sand dune ecosystem since the disappearance of the original dunes because of the building process. In addition, these buildings generate a 'screen effect' that prevents the sand flowing from the Mediterranean coast into the Mar Menor one.

The original situation of La Manga was a line dune with prevailing easterly winds. This wind moves the sand from the beaches of the Mediterranean, through the dunes of La Manga to the beaches of the Mar Menor. So the beaches of the Mar Menor obtain their sand from dunes and beaches of the Mediterranean Sea in the east. Currently, the disappearance of the dunes and the socalled 'screen effect' leads the western beaches to lose sand continuously and owners see that salt water from the lagoon is nearing the foundations of their buildings (Fig. 13). This phenomenon is still requires a rigorous study to evaluate the extent of the problem.

Another important coastal problem that generates several controversies is the sea level rise. In the near future, where it seems foreseeable that there will be a significant increase in sea level due to climate change, the equilibrium could break between filling and the relative rise in sea level of the coastal lagoons.

Nonetheless, this problem should be studied with scientific rigor. Decreasing rains in the region, in coherence with the rise in average temperature, estimated between $0.6^{\circ} \mathrm{C}$ and $0.8^{\circ} \mathrm{C}$ in the last century, involves a parallel increase in the average sea level evaluated at $0.55 \mathrm{~mm} /$ year during the last century, as can be seen in Serra [3]. Unjustified alarmism such as that posed by some environmental associations does not help to raise realistic strategies and undermines the credibility of the results to the political authorities. The modification of the sea level will lead to important consequences for low coasts such as the Mar Menor, in which the backward movement of the coast is ranked at around a metre per centimetre of rise in sea level [14]. This situation contrasts sharply with the environmental campaigns of 2007 (Fig. 14) but shows the need to establish policies for the longterm sustainability for an environment as fragile as La Manga and the Mar Menor.

\section{IMPACTS RESULTING FROM AGRICULTURAL LAND TRANSFORMATION IN THE SURROUNDINGS OF THE MAR MENOR}

Despite the importance of the massive urban development activities in different parts of the coastal perimeter of the Mar Menor, the biggest environmental impact on the salt lake is paradoxically far from it. The Mar Menor is situated at the end of a big watershed delimited by a group of mountain 


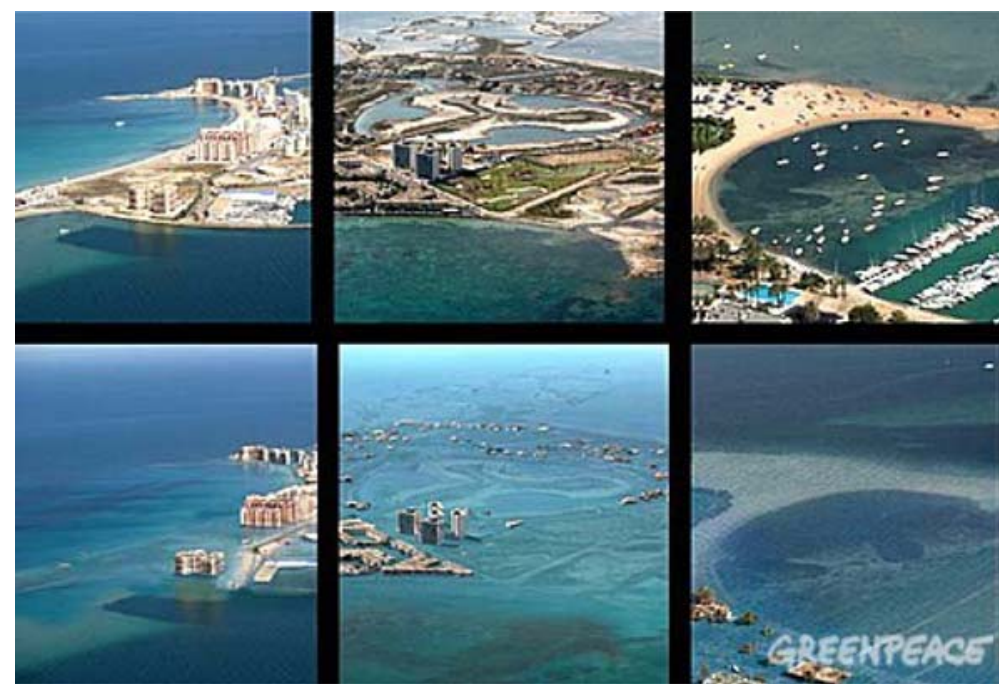

Figure 14: Future effects of climate change on several places of La Manga of Mar Menor according to Greenpeace. Source: PhotoClima, 2007.

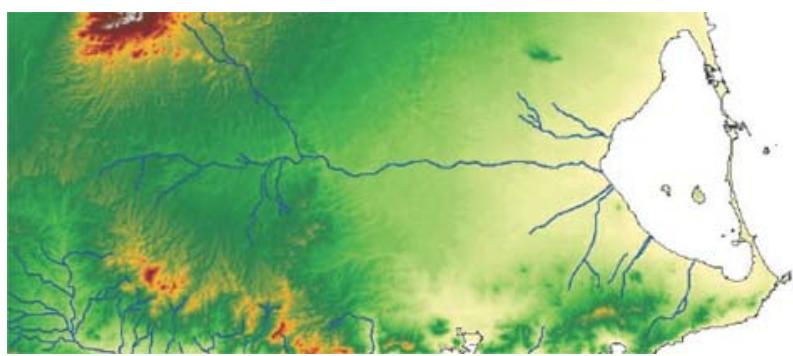

Figure 15: Digital Elevation Model of the wadis area. Source: IDERM and authors.

ranges that surround the area of the Campo de Cartagena, an extensive plain of about 1,440 $\mathrm{km}^{2}$. Freshwater inputs into the lagoon are restricted to six ephemeral watercourses called 'wadis' or 'ramblas' in Spanish. As stated before, these wide and shallow gullies are generally inactive but can carry large quantities of water and sediment during the traditional Mediterranean flood episodes of autumn. The torrential nature of the supplies is aggravated by the impermeable soils and scarce vegetation cover of the watershed areas going directly to the Mar Menor (Fig. 15).

The Campo de Cartagena is now an intensively irrigated area where agriculture constitutes the main land use (Fig. 16). El Albujón wadi constitutes the most important watercourse and drains the adjacent agricultural area of the Campo de Cartagena. The Miranda wadi presents two main channels that converge diffusely in the Carmoli salt marsh. The other three wadis are less important as was shown in Section 2, and do not usually carry with inputs related to agriculture.

The Albujon is the principal watercourse, draining a surface of $441 \mathrm{~km}^{2}$, about one-third of the total surface of the Campo de Cartagena. Since 1980, it has flowed permanently into the lagoon due to a surplus of irrigation water. The Albujon watershed, of $42 \mathrm{~km}$ length, presents a fan form with 


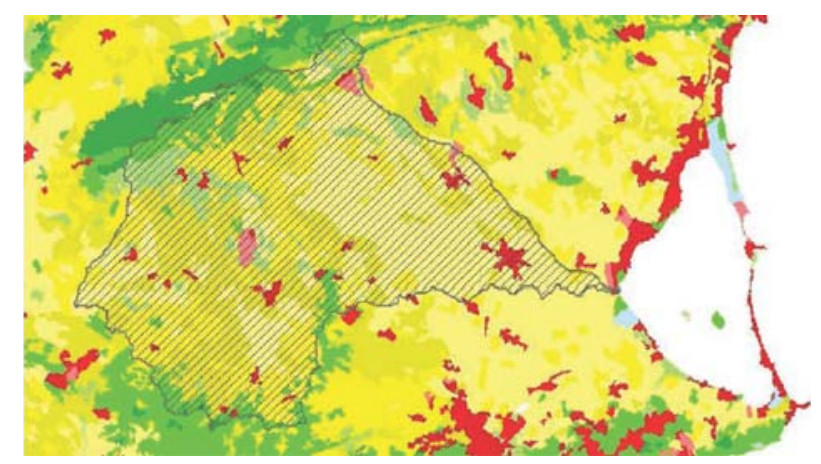

Figure 16: Land uses in the Mar Menor area and El Albujón watershed. Source: Corine Land Cover 2006, IDERM and authors.

the low section constrained to $<2 \mathrm{~km}$ width. According to Conesa [15], the drainage network is dendritic, with a low drainage density. The tributaries are concentrated in the upper section of the watershed, while the last $20.5 \mathrm{~km}$ of the principal channel is without tributaries. The mean watershed slope is $3.02 \%$, but ranges from $25 \%-30 \%$ at the head to $<1 \%$ in the lowland section and the mouth.

According to Lloret et al. [16], in normal local climatic conditions, the Albujon wadi is fed by land-based points and diffuse sources. The principal source is the drainage of irrigated crops, but sometimes, the Alcazares town waste-water treatment plant, located in the watershed area, discharges large amounts of untreated or insufficiently treated water originated from tourism into the channel. This severe episodic pollution occurs especially after storms and in summer months when the population of the inland coast of the Mar Menor increases from 30,000 to 200,000 inhabitants. During heavy rains, the Albujon wadi is fed principally by surface runoff. The drainage waters collected by channels meet at a pumping plant next to the Albujon mouth (at $100 \mathrm{~m}$ distance). The water is pumped to a desalination plant, but any surplus water is discharged directly into the lagoon (drainage effluent).

In the study, which was published in 2006, using five control stations in different places of the Mar Menor [17], the important environmental impact of these inputs from the Albujon wadi to the lagoon was clearly demonstrated.

According to Velasco et al. [17], 81\% of the nutrient and particulate inputs arriving into the Mar Menor lagoon belong to the intensive agricultural watershed of the Albujon wadi and cause an important process of eutrophication in the lagoon [14].

These inputs are the food for some new species that have colonised the lagoon and the cause of the exponential growth of some of them, such as the jellyfish Cotylorhiza tuberculata. These results are obvious. Nevertheless, it must be taken into account that the origin of the appearance of this species comes from the change of boundary conditions generated by the phenomenon called 'Mediterranisation' described in Section 3. This phenomenon, as a result, has caused a lot of damage to tourism and requires expensive and frequent massive collections every year (Fig. 17).

It must be noted that in this complex problem of managing the environmental impacts in the Mar Menor, the absence of environmental planning to regulate the pollution coming from the area of the Campo de Cartagena should also be mentioned. The Mar Menor is a maximum protection element in the Natura 2000 network of the Region of Murcia (a zone on the other side with most of its territory subject to some environmental protection figure). Nevertheless, the adjacent area of the Campo 

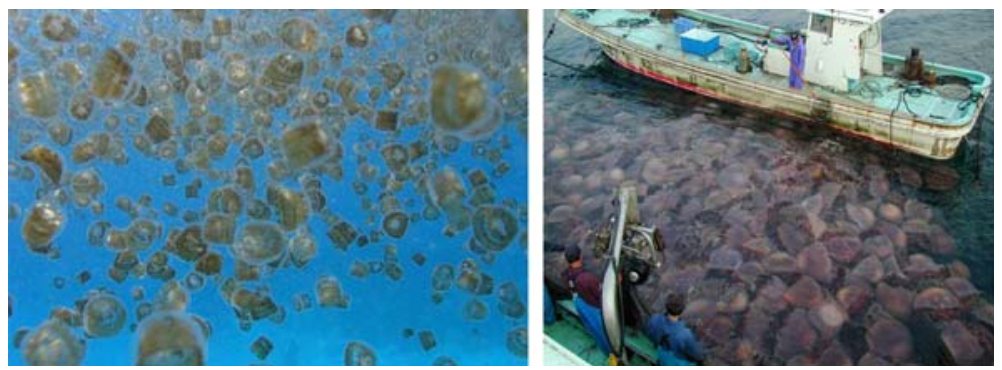

Figure 17: Massive presence of Cotylorhiza tuberculata in the Mar Menor (left). Collection of jellyfish by fishing boats (right). Source: La Verdad Newspaper 03/08/2011.
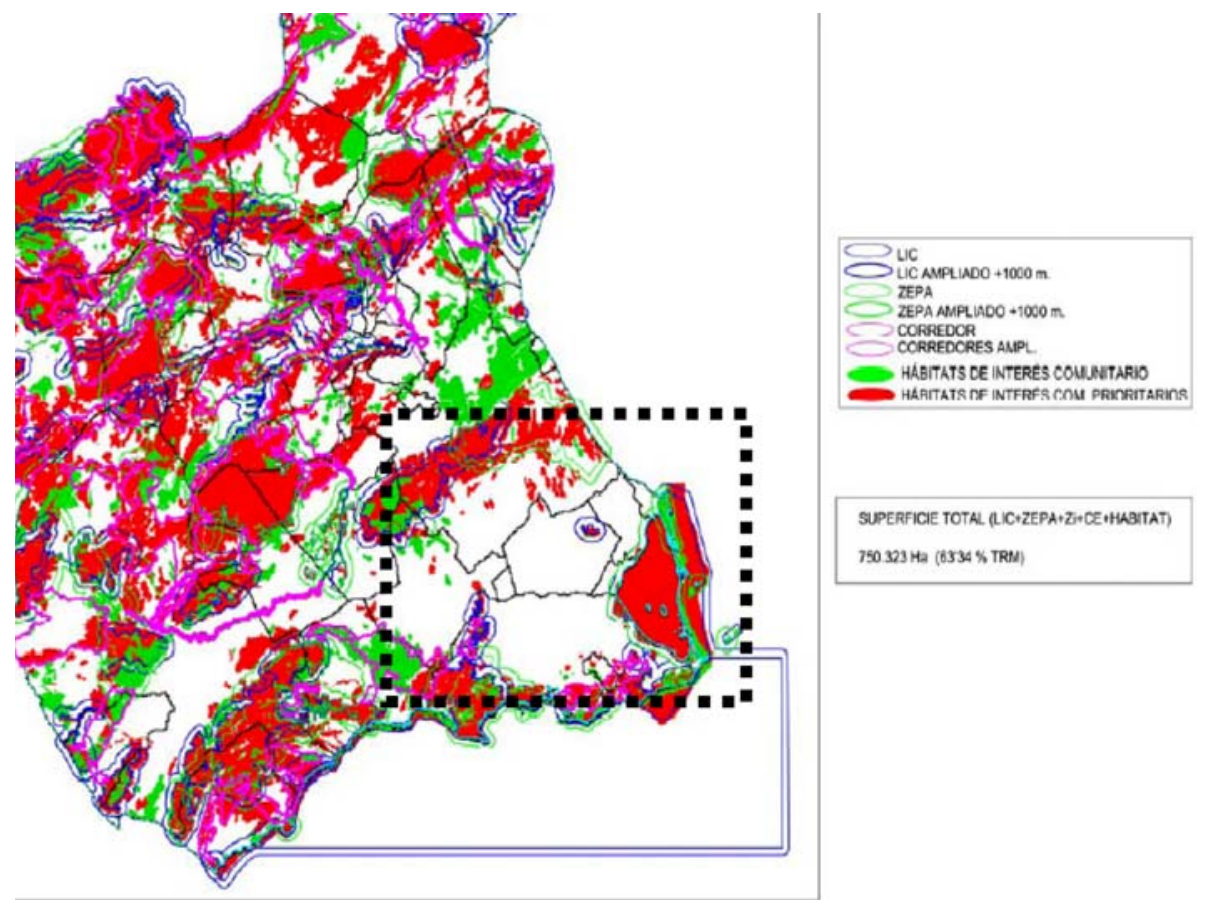

Figure 18: Several figures combined into one from Natura 2000 network in the Region of Murcia. Source: IDERM and authors.

de Cartagena that causes the problem studied is paradoxically one of the areas with least environmental regulation (Fig. 18).

The Mar Menor is currently managed within a complex legislative and policy context, with a wide variety of institutions and actors involved in the use and management of the lagoon. It is therefore necessary to develop a framework of common objectives and urban management guidelines in order to promote a more sustainable development in the area and protect its natural resources and biodiversity, especially facing the expected consequences of future global climate change. 
Table 4: Protected areas and territorial tools in the Mar Menor.

\begin{tabular}{lllll}
\hline Protected area & Protection tool & Municipality & $\begin{array}{l}\text { Surface } \\
(\mathrm{Ha})\end{array}$ & $\begin{array}{l}\text { Protection } \\
\text { regulations }\end{array}$ \\
\hline $\begin{array}{l}\text { Calblanque, Monte } \\
\text { de las Cenizas y Peña } \\
\text { del Águila }\end{array}$ & Regional Park & $\begin{array}{l}\text { Cartagena and La } \\
\text { Unión }\end{array}$ & 2,822 & $\begin{array}{l}\text { 4/92 Act PORN, } \\
\text { Decreto 45/1995 }\end{array}$ \\
$\begin{array}{l}\text { Salt flats and sands of } \\
\text { S. Pedro }\end{array}$ & Regional Park & $\begin{array}{l}\text { S. Pedro del Pinatar } \\
\text { and S. Javier }\end{array}$ & 856 & $\begin{array}{l}\text { 4/92 Act } \\
\text { PORN Decreto } \\
\text { Cabezo Gordo }\end{array}$ \\
$\begin{array}{llll}\text { Protected } \\
\text { landscape }\end{array}$ & Torre Pacheco & 281 & $4 / 92$ Act \\
$\begin{array}{l}\text { Open spaces and } \\
\text { islands of the Mar } \\
\text { Menor }\end{array}$ & $\begin{array}{l}\text { landscape } \\
\text { Cartagena, Los }\end{array}$ & $\begin{array}{l}\text { Alcázares and } \\
\text { S. Javier }\end{array}$ & 1,186 & $4 / 92$ Act \\
\hline
\end{tabular}

Source: authors.

The management of all these variables is not simple from the territorial point of view. The environmental impact of all these parameters on the Mar Menor is legally distributed in various instruments and plans that are the responsibility of different authorities. The division of responsibilities is as follows:

- At national level, these are national coastline plans, affecting the first $100 \mathrm{~m}$ of shoreline.

- At regional level, Regional Land Use Plans and Sectorial Plans define the regional strategy for territorial development and the Protected Areas Land Use and Management Plans (PORN). These plans are still unfinished and have been slowly developed for more than 20 years.

- At municipal level, Municipal Urban Plans (PGOU) are regulatory instruments that establish the land use regime of the municipalities. These are the most effective instruments in the territorial management in Spain, due to their capacity to regulate the whole land transformation.

\section{CONCLUSIONS}

In this article, the following conclusions must be highlighted:

- The Mar Menor lagoon is subject to many environmental impacts. Of these, the most important are the urbanization process in La Manga and land transformation of the territory of the Campo de Cartagena.

- In the urbanization process, the screen effect created by the buildings of La Manga is responsible for the major swings of shorelines because of the dynamic alteration of the natural coastline.

- On the other hand, there is a well known and studied problem of eutrophication of the Mar Menor due to discharges from the drag of agricultural chemicals from the Campo de Cartagena runoff. In this field, it must be added that the current problem of the proliferation of jellyfish in the Mar Menor is not a direct consequence of this phenomenon alone but the combined effect of the latter with the 'Mediterranisation' process of the Mar Menor generated by the so-called sump effect of the Tomas Maestre port. This effect is probably due to Estacio channel dredging during the urbanization of La Manga. 
- All these impacts, together with the absence of proper environmental planning in the Campo de Cartagena, indicate the current need for a new specific territorial planning tool based on multidisciplinary technical criteria for the future management of the area of the Mar Menor.

\section{REFERENCES}

[1] Martinez, J., Esteve, M.A., Martínez-Paz, J.M., Carreño, F., Robledano, F., Ruiz, M. \& Alonso, F., Simulating management options and scenarios to control nutrient load to Mar Menor, Southeast Spain. Transitional Waters Monographs, 1, pp. 53-70, 2007.

[2] Miralles, J.L. \& García-Ayllón, S., The economic sustainability in urban planning: case La Manga. WIT Transactions on Ecology and the Environment, Vol. 173, WIT Press: Southampton, pp. 279-290, 2013.

[3] Serra, J., EUROSION Case Study: Mar Menor. Institut de Ciència i Tecnologia Ambientals. Universitat Autònoma de Barcelona.

[4] García-Ayllón, S., En los procesos de urbanización del mediterráneo: el caso La Manga. PhD thesis, Polytechnic University of Valencia (Spain), 2013.

[5] IDERM, Infraestructuras de datos espaciales de la Región de Murcia. doi: http://www.cartomur.com/,doi: http://www.iderm.imida.es/geoportal

[6] Miralles, J.L. \& García-Ayllón, S., The urban metamorphosis of La Manga and the "mediterraneanisation" process of the Mar Menor (Spain). WIT Transactions on Ecology and the Environment, Vol. 169, WIT Press: Southampton, pp. 53-64, 2013.

[7] Miralles, J.L., Díaz, S. \& Altur, V.J., Environmental impact on the Mediterranean Spanish coast produced by the latest process of urban development. WIT Transactions on Ecology and the Environment, Vol. 155, WIT Press: Southampton, pp. 379-389, 2012.

[8] Pérez-Ruzafa, A., Navarro, S., Barba, A., Marcos, C., Cámara, M.A. \& Salas, F., Presence of pesticides throughout trophic compartments of the food web in the Mar Menor lagoon (SE Spain). Marine Pollution Bulletin, 40, pp. 140-151, 2000. doi: http://dx.doi.org/10.1016/ $\underline{\mathrm{S} 0025-326 \mathrm{X}(99) 00193-9}$

[9] Arévalo Díaz del Río, L., Intercambios en el estrecho de Gibraltar y su respuesta a forzamientos meteorológicos y climáticos. Proyecto de Investigación, Universidad de Málaga, Ministerio de Educación (Spain), 2006.

[10] IA Consultores. Estudio de Impacto Ambiental de Puerto Mayor. 1995.

[11] Estudio de la dinámica litoral de la costa peninsular mediterránea. Provincias de Murcia y Alicante. Ministerio de Obras Públicas y Urbanismo (Spain), 1979.

[12] Coastal Oceanographic Observatory of Murcia, www.oocmur.es

[13] Judgment 584/2010 of the Administrative Litigation Division of the High Court of the Region of Murcia from 18/06/2010. The works continue and paralyze were determined according to a technical report made by the engineer expert José Luis Monsó Prat.

[14] Mas, J., El Mar Menor. Relaciones, diferencias y afinidades entre la laguna costera y el mar Mediterráneo adyacente. PhD Thesis. Universidad Autónoma de Madrid.

[15] Conesa, C., El Campo de Cartagena. Clima e hidrología de un medio semiárido. Universidad de Murcia, Ayuntamiento de Cartagena y Comunidad de regantes del Campo de Cartagena. Murcia, 1992.

[16] Lloret, J., Velasco, J., Bello, C. \& Marín, A., The Mar Menor Lagoon - Current knowledge base and knowledge gaps. Lagoons. 2012. Lagoons Report D2.1c. 65pp. University of Murcia, Spain.

[17] Velasco, J., Lloret, J., Millan, A., Marin, A., Barahona, J., Abellan, P. \& Sanchez-Fernandez, D., Nutrient and particulate inputs into the Mar Menor lagoon (SE Spain) from an intensive agricultural watershed. Water, Air, and Soil Pollution, 176(1-4), pp. 37-56, 2006. 